\title{
Jurntu Purlapa-Warlpiri songline for the Jurntu Fire Dreaming site (Australia)
}

Barbara Glowczewski, Jerry Jangala Patrick and Mary Laughren

\section{(2) OpenEdition \\ 1 Journals}

Electronic version

URL: https://journals.openedition.org/clo/8733

DOI: $10.4000 /$ clo.8733

ISSN: 2266-1816

Publisher

INALCO

\section{Printed version}

Date of publication: 30 June 2020

Number of pages: $225-231$

ISBN: 978-2-85831-392-1

ISSN: 0396-891X

\section{Electronic reference}

Barbara Glowczewski, Jerry Jangala Patrick and Mary Laughren, “Jurntu Purlapa-Warlpiri songline for the Jurntu Fire Dreaming site (Australia)", Cahiers de littérature orale [Online], 87 | 2020, Online since 16 September 2021, connection on 09 November 2022. URL: http://journals.openedition.org/clo/8733 ; DOI: https://doi.org/10.4000/clo.8733

\section{(c) (†) \$}

Creative Commons - Attribution-NonCommercial 4.0 International - CC BY-NC 4.0

https://creativecommons.org/licenses/by-nc/4.0/ 


\section{Jurntu Purlapa ${ }^{1}$ - Warlpiri songline for the Jurntu Fire Dreaming site (Australia)}

Barbara GLowCZEwski

Jerry Jangala PATRICK

Mary LAUGHREN

The Jurntu Purlapa songline was dreamt in the 1960's by Janjiya Liddy Nakamarra Herbert who, after her sacred boards yukurrukurru² were mysteriously burnt, was delirious for a month until she saw three Jampijinpa ${ }^{3}$ rainmakers painted with Fire and Python designs connected with the Jurntu sacred site in the Tanami desert. The spirits came out of a hollow log in Lajamanu where she

1. General term for public rituals with mixed dances where men and women sing together.

2. Wooden oblong boards restricted to women who repaint them with totemic designs at each of their ritual performances that they call Yawulyu. Women then dance carrying their boards, painted like their breasts with a kuruwarri, a force-image that is mapping one or more sacred sites made, marked and named by their respective totemic ancestors, the Dreamings, Jukurrpa.

3. Jampijinpa is one of eight "skin-names" (subsections) which form together a system of classificatory kinship and inter-relations (dihedral group of eight figured by the properties of a cube in mathematics): it connects all Warlpiri through different relations of kin and alliance: a Jampijinpa calls all the Jampijinpa men and Nampijinpa women his "skin brothers and sisters," all the Jangala his "skin fathers" (all Nangala his paternal aunties), the Nungarrayi are his "skin mothers" (all Jungarrayi are his "skin maternal uncles," he can only marry with a Napangardi whose brothers are Japangardi, fathers are Japanangka (paternal aunties Napanangka) and mothers are Napurrurla (maternal uncles Jupurrurla), etc. 
lived, and showed her a new public ritual (purlapa) enacting how one of them, Wirrilwirrilpa, was chased and killed by his uncles for breaking a funeral law in the 1930's. Janjiya identified him as being responsible for the burning of her boards. She gave the new songs and body designs to the men to dance his historical punishment, and to the women to paint on their breasts and yukurrukurru boards for their Fire yawulyu ritual. Her testimony and the ritual jointly sung by men and women were recorded by the anthropologist Barbara Glowczewski in 1984 in Lajamanu: the message was for the Warlpiri to accept living in this Central Australian reserve that was established in the early 1950's on the land of their Northern neighbors, the Gurindji. In 2011 Warlpiri elder Jerry Jangala Patrick $(\mathrm{JJ})^{4}$ translated the Jurntu recording for linguist Mary Laughren (ML). ${ }^{5}$

Pirntipirntirla ngapin-kanganya "It is lining up on the side"

Kangkarni jiirl-kujurnu "It has risen"

JJ: After the smoke has risen, a cloud (ngangkarli) forms. Ngapin-kanyi is "lined up beside something."

Lirranji mamali-manu "The smoke from the bush fire formed a white cloud" Pirntipirntirla kayarr-kangurra "It arose along the side"

JJ: Cloud of smoke (lirranji) rising up in sky as white cloud from bush fire Dreaming at Mongrel Downs. Mamali-manu is for the white smoke (ML: lirranji $=$ Pyrocumulus; pirntipirnti $=$ side of $)$.

Jurtururrumparna warra-kanjani "I'm walking among the Jurtururrumpa trees" Yangarrurnturna warra-kanjani "I'm walking all alone"

4. Lead singer during the 2018 Milpirri Festival (https://tracksdance.com.au/2018milpirri-jurntu); Glowczewski was then asked to screen Lajamanu (https://vimeo. com/289440509), her 60' film including two scenes with Jerry Jangala who dreamt in the 1970's a Christian purlapa for the Warlpiri Baptist Church.

5.See Glowczewski (2016) and her Warlpiri audiovisual collection with collaborative annotations stored on www.odsas.net. Singers of the 1984 Jurntu purlapa: Ronnie Jakamarra Lawson, Jimm Jampijinpa Kelly, brothers Jimmy and Lesleigh Jampijinpa Robertson, Bob Leo Japaljarri Payton, Jungarrayi Powder, Yakiriya Maisie Napangardi, Kungariya Gladys Napangardi, Panyinyi Alice Napaljarri, Wiyikala Nora Nungarrayi. Jakamarra, the three Jampijinpa and eight other men were invited to Paris to perform the dance at the Peter Brook's Theatre, and to make a related ground painting at the Museum of Modern Art; Jimmy Robertson came back for a 2001 Unesco conference were he sang some verses about the spirit resting in Jurntu. 
JJ: Red ground country with trees called Jurtururrumpa that people find as they are looking around. Some words in Bilingarna language. Stranger is walking along and finds that this is beautiful country and sings about it. Old Jampijinpa called Wirrilwirrilpa was killed in this country by his own countrymen.

Yangarrurnturna "I'm all alone in my country" (like yangarlu "alone").

Jutumarurru ngayirrirntimparna kayarr-kanjani

JJ: Walking along slowly, ngayirrirntimparna "I'm getting close now." Ngayirri is being alone and feeling sad. Jampijinpa karlarra-wardingki "Jampijinpa was a person from West." Yarntarn-kangu is the name of the father of Popeye Jangala who lives at Ringer Soak. Jutumarurru is "going along straight," like jukarurru, jingijingi "straight, direct" (ML: Gurindji ngayirrap "homesick;" Jaru jutu "straight").

\section{Wirrirnta wirrirn-wirrirnta}

Ngayirlirlirna ngarntarl-wantinya

JJ: He's fallen down now, fallen down side ways (from everyone hitting him).

Milpirinpalurna kangu "Into the night dance I joined"

Jurntu-jurnturla janta-kangurra "Joined in at Jurntujurntu"

$\mathrm{JJ}$ : Milpirinpa is munganpirdi, the night time dance (ML: munganpirdi "middle of the night"). Old Jampijinpa Yarntarnkangu comes from west to a place where his brother Wirrilwirrilpa was killed by his relations, at Jurntu. Jantakanyi is luntu-kanyi "join in" (ML: Yarntarnkangu "light walker, one who sneaks up quietly").

Panga-pangalu janta-kangurra "Walking with legs apart they joined in"

Milpirinpalurna janta-kangurra "Into the night dance they joined"

JJ: Panga-panga "walking with legs apart" (ngarnta-ngarnta in Warlpiri), also used for kangaroo running away with baby in pouch.

Ngarnkarna yuwalinji-ngirli "I looked back at Ngarnka from Yuwalinji"

Yurrumurntumurntu-kangu "Brought everything"

JJ: He's looking back at Ngarnka hill (kurlirra "south" side, south from Tanami) and is singing about bringing everything from there to ceremony place.

Wirrirntirtirnpa Lamarnpa "Looking around he saw a hollow-tree" Kari-nyangurra jutu-pungurra "Ignorant of what it was he stopped" 
JJ: Lamarnpa looked around and didn't recognise what it was, thinking it was a tree with a hollow in it and he stopped from going any further. (ML: lamarn "hollow" in Jaru language). Lamarnpa is wilypiri "tree hollow." Old Japanangka was called Lamarnpa from Lamarn-jukurpa “Tree-hollow-Dreaming." Man in story might mistake someone or something for a hollow in tree, or tree with hollow. He stops there and goes no further (ML: kari-nyangurra "failed to recognise," jutu-pungurra "desist, stop and go no further/leave off").

Warlarrirlarna jutu-pungurra "At a Supplejack tree I stopped and went no further" Puyuluwarrarna "I walk away feeling glum" (813)

JJ: Warlarri "Supplejack tree;" yani puyuluwarra "he goes sad, glum face" (ML: warlarri "White Gum Tree" in Jaru language, equated by JJ with Warlpiri walakarri)

Jampijin warrawarrarla kijiwangurru "Jampijinpa saw all the bones"

Warra-kanjani kijiwangurru "Looked closely at all the bones"

$\mathrm{JJ}$ : Another Jampijinpa is coming up from east-Barrow Creek way. Big mob of bones, one Jampijinpa looks and thinks he can see all the bones of the other Jampijinpa. Jarraly-kanjani "coming along looking" (ML: kiji "bone" in Jaru language; kijiwangurru "no small amount of bones").

Lirrakurlukurlu jalili-pungu "He was struck down and smashed by the boomerang"

Kuwaliwali jalili-pungu "He was smashed to pieces"

$\mathrm{JJ}$ : kuwaliwali means body is struck and breaks up into pieces that are scattered from force of boomerang. Wawulja kills Mungkuparlpa. "The two Japaljarri men, Wawulja and Mungkuparlpa, pelt each other with boomerangs.”

Ngarlirna kingkil-wantinya "Sideways I fall down dead"

Kingkirlarrarlu kingkil-wantinya "Fell down dead"

JJ: Wantija walya-kurra ngarlikipurda karli-jangka luwarninja-warnu Mungkuparlpa. "Mungkuparlpa fell down to the ground on his side after being struck by a boomerang." Old Jampijinpa was singing about those Dreamings of two Japaljarri men (Wawulja and Mungkuparlpa) who hit each other with boomerangs. ${ }^{6}$

6. Reference to Invincible (Wawulja) married to his daughters he asked to kill any sons. They hid two boys, who became the Watijarra (Two Men) Dreaming and pushed Mungkuparlpa to attack Wawulja who hit back, the body of the foreigner exploding and 
Mantawariji kari-nyangurra "He couldn't recognize the country"

Nginjurlurrurlurru jurnturrurl-pungu. "His legs gave way under him and he collapsed"

JJ: Nyurru wantija walya-kurra, "He had fallen down on the ground," he couldn't recognise or understand what country he was in (mantawariji is walya "country, earth"). He fell down and died. Nyunjurlurrurlurru is the Warlpiri for legs that are weak and give way under you, like they just double up and the person falls down because legs can't keep you up-standing. (ML: manta is earth, ground in Western Desert languages e.g., Kukaja).

Ngarntakurlarna ngarntarl-wantinya "I have fallen down on a tree fork"

Jalyirrpa milyilyiparnka "I have been covered with leafy branches"

JJ: I'm lying down under the leaves, I fell down. Milyilyiparnka is for parntayirrarninja-warnu jalyirrpa-warnu "having been covered with leaves/leafy branches."

Winjirri-manpa karntirri-pungu "Water is spurting out of you where you were impaled on tree"

Winjirri-manpa pantupanturnu "Water from where you were pierced"

JJ: Water is shooting (spurting) out from your body (of dead man) (ML: winjirri "spring" also refers to bodily fluid or liquid that oozes out of corpse, may be source of spring).

Manja-manjarla kawarr-kangurra "Lost in the thick Mulga scrub"

Mamarrilpalurna nyanya "I saw his spirit"

JJ: Mamarrilpa is pirlirrpa "soul, spirit, life-force." Looking at the spirit of dead man. Manja-manja is wardiji, mulga country, or place with lots of trees. (ML: kawarr-kangu can mean "get lost" or "get exhausted, weary" or "die;" I think that kawarr-kanyi and kayarr-kanyi may be variant ways of pronouncing the same word, but am not certain; I had recorded kawarr previously).

Kartarlarlarna kayarr-kanjani "Lost in the wrong country"

Jujungka kayarr-kanjani "Lost where the (bad) spirit is"

JJ: Juju is pirlirrpa... kartarlarla is going to wrong place, nguru-karirla “another country" (ML: i.e., not one's own place). Kartarda is Wilson Creek.

turning into rocks of different sacred sites. The sons gave kinship systems and healing powers to different language groups (Glowczewski, 2016). 
Probably means in dry country (kartarla is not a Warlpiri word). (ML: pirlirrpa "soul, spirit;" juju "ceremony, Dreaming spirit...") Jutu is "straight," as in walking along straight track. Might be walking in jurdu "dust" or willywilly (whirlwind). Not sure of meaning of these words.

Kunawurruwurru yuwalany-pungu "Sent up dark poo-like clouds"

Yiwalinjirna yuwalany-pungu "Sent up mass of clouds in form of a nest"

JJ: Bush fire is sending up black smoke into the sky and making mess like person/animal defecating, and then the smoke stands there in the sky like a nest. (ML: yiwali/yuwali "nest;" yuwalany-pungu "cause clouds to gather;" kuna "excrement")

Tapungkarlarna kayarr-kanjani "In Rdapu..."

Jarnajarnarla/kajarlarlarna kayarr-kanjani "After fire..."

JJ: Tapu, Rdapu place where two Dreaming men make a fire from firesaw (jiwinypa) near Kulpurlunu. Place is called Rdapu. Jarnajarna is after fire, behind fire.

Karrijirdirna jarnangkurr-manu "I lifted up the gully"

Warlurna jarnangkurr-manu "I lifted up the fire"

JJ: Karrijirdi "gully" where water runs through hills. Jarnangkurr-manu "lift up" like mirage lifting up the country to make it visible, lifts up the gully where water flows.

Mangkurdurlarna warrawarrarla "Seeing the clouds"

Ngarnkangka tawarrawarra "Straight ahead at Ngarnka"

Ngarnkangka yirlarrirlarri "At Ngarnka all red"

Yurnturna nyangu "I saw them closeup"

JJ: yurnturra-nyangu Yirlarrirlarri is "see lots of red hills or red stones close up." (ML: yurnturr “cloud” in Jaru \& Walmajarri languages)

Wuријитијити ширијирији "Walking sliding feet"

Yirlingkurrparna

$\mathrm{JJ}$ : жиријurujuru is walking sliding feet over the ground. Same meaning for wиријиријu. Yirlingkurrpa might be name of country that spirit (mamirrilpa) is singing about. Might be his country. (ML: yilangkurrunyu "Blue Mallee"possibly related) 


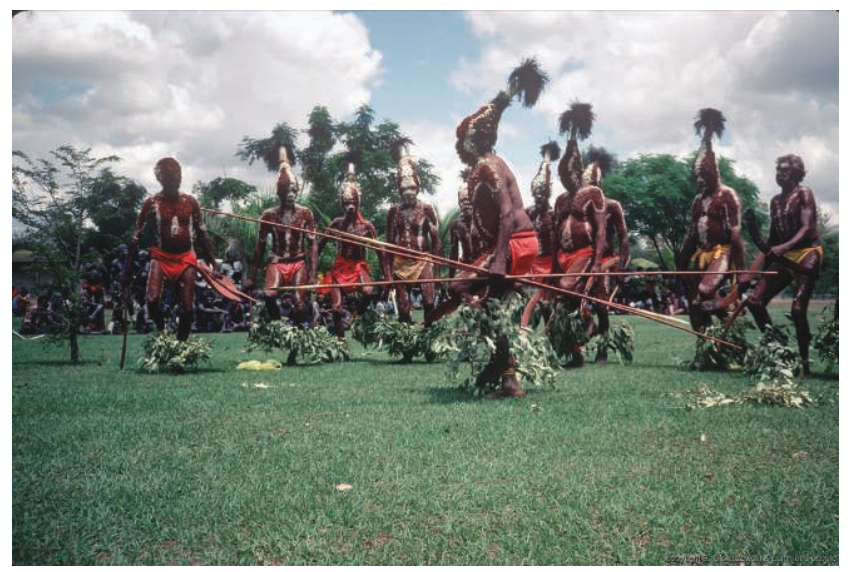

Illustration 1

Abe Jangala and Lajamanu men dancing the Jurntu purlapa, Katherine, 1984,

Cliché : B. Glowczewski

Pinkirrpa wirirri-kangu "Feather flew away"

Manta-mantarla jarnmurru-kangu "Came crashing down on the ground"

JJ: Walya-kurra-jarrija "landed," lands like parachute (jarnmurru-kangu "crash land"). Pinkirrpa "feather, wing" travelled from Patirlirri to Tanami Jukurpa (Dreaming). Wirirri-kangu "fly from one country" (ML: referring to Budgerigar Dreaming from Patirlirri on Lander River to east).

\section{Bibliography}

GlowCZewski Barbara, 2016, Desert Dreamers. Warlpiripeople from Lajamanu, Minnesota University press/Univocal, Minneapolis, 250 p., [traduction augmentée de Les Rêveurs du désert, Plon, 1989].

Laughren Mary \& Turpin Myfany, 2013, "Edge Effects in Warlpiri Yawulyu Songs: Resyllabification, Epenthesis, Final Vowel Modification" in Australian Journal of Linguistics, $\mathrm{n}^{\circ} 33$ (4), pp. 399-425. 